\title{
Review
}

\section{Political responsibility: Responding to predicaments of power}

\author{
Antonio Y. Vázquez-Arroyo \\ Columbia University Press, New York, 2016, xxi + 334pp., \\ ISBN: 9780231174848
}

Contemporary Political Theory (2017) 16, 561-565. doi:10.1057/s41296-017-0091-5; advance online publication 11 January 2017

Antonio Vázquez-Arroyo's Political Responsibility: Responding to Predicaments of Power is a thoughtful, bold, and refreshing work. He criticizes "depoliticized politics" in the name of democratic socialism and rejects apolitical conceptions of responsibility, calling instead for a realist "political ethic of responsibility" mediated by social, political, economic, and cultural forces. Vázquez-Arroyo attributes the depoliticization of responsibility to abstraction from concrete political realities; the attribution of reality to theoretical constructs ("hypostatization"); and the resulting depoliticization of politics itself. While that account is persuasive, Vázquez-Arroyo ironically dismisses these as vices rather than acknowledging them as necessary moments in the mediation of his own conception of political responsibility that must be subjected to political judgment. In my judgment, his mediations result in an unsettling distinction between necessary and superfluous suffering that seems to devalue some lives as disposable ones in the struggle for what he identifies repeatedly as "genuine" freedom, democracy, and equality.

Vázquez-Arroyo argues that any truly political responsibility must respond to "predicaments of power" mediated by concrete situations. The path he takes is fascinating, but circuitous enough that he occasionally risks losing the reader. Vázquez-Arroyo approaches responsibility as a "problematic" and offers " "not a head-on, direct solution or resolution, but a commentary on the very conditions of existence of the problematic itself'" (p. xi). After historicizing the ethical turn in the social sciences and humanities (ch. 1), which he holds partly responsible for depoliticizing responsibility, he turns to an historicization of the concept of responsibility itself (ch. 2). Taking us from Aristotle through Rome and the European Enlightenment to our neoliberal present, he demonstrates that "responsibility" - which once referred to practices of accountability that guided "the life of the individual in a concrete collectivity" shaped by predicaments of power (p. 67) is "comprehensively disavowed" under neoliberalism (p. 103). Its "processes of

(c) 2017 Macmillan Publishers Ltd. 1470-8914 Contemporary Political Theory Vol. 16, 4, 561-565 www.palgrave.com/journals 
social and political 'disaffiliation,' long underway, are exacerbated in an age in which neoliberal responsibility praises individual self-reliance while...making social and economic independence" ever more tenuous (p. 103).

The neoliberal depoliticization of responsibility is abetted by an intellectual turn away from politics and into subjects themselves. In chapter 3, Vázquez-Arroyo argues that the ethical turn produced a "proliferation of solipsistic philosophical accounts of responsibility" that "engage in Platonic soul-crafting and dwell on the inner life of the subject" (p. 105). In another sweeping story, he begins with Kant's turn to intrasubjectivity and passes appreciatively through Hegel's "determinate responsibility" that culminates in "the idea of citizenship as a productive activity whose actions are the basis for freedom and responsibility" (p. 115). He laments Nietzsche's aristocratic tendencies that "[deflate] any sense of responsibility for existing suffering and [dismiss] it as... a chimera of the weak" (p. 130); and brings us to analytic philosophy, which he derides as "so deadening, or marred by stunted commonplaces that symptomatize anodyne platitudes about the afflictions supposedly besieging present-day liberal democracies, as to make one cringe" (p. 130). This tone, which Vázquez-Arroyo occasionally adopts elsewhere, sometimes overshadows an otherwise thoughtful critique. He pursues the charge of solipsism in chapter 4, taking aim at Levinas' critique of autonomy in the name of the Other and its legacies in the work of Butler and Derrida. He charges Levinas with a "flight from history and political life," with abstraction and depoliticization that "[risk] futility" (p. 145) because the immediacy of Levinasian responsibility forestalls any mediation of a "constitutive situation" (p. 150). But the "hypostatization" of the Other, for Vázquez-Arroyo, is the ultimate depoliticization. Derrida extends Levinas' inattention to real politics, while Butler's move from infinite responsibility to an ontology of shared vulnerability similarly flattens out the texture of political life (pp. 150-180).

The bulk of Political Responsibility is diagnostic: Vázquez-Arroyo charges existing accounts of political responsibility with being overly abstract, hypostatizing, and depoliticizing. He presents an impressively comprehensive historicization and critique of these accounts that is quite persuasive, but he doesn't leave himself enough space to develop the alternative he proposes in the final two chapters. Those crucial chapters raise troubling conceptual and political questions. Vázquez-Arroyo draws on a diverse array of writers - Adorno, Brecht, and Weil, as well as Machiavelli and Weber - to outline a genuinely political ethic of political responsibility. The "primacy of the situation" (p. 218) and its mediations of political responsibility are at the core of that ethic. A "political ethic" describes an approach to concrete situations driven by and reflective of the tension between ethics and politics. Vázquez-Arroyo desires a politics in which "the people" seize crucial political moments (in a collective exercise of Machiavellian virtù) in accordance with Weberian virtues of "passion, a sense of responsibility and 
proportion" that balance an "ethic of conviction" with "an ethic of responsibility" (p. 219); that recognizes both the tragic necessity of force (à la Weil) and the limits of an ethical politics (à la Brecht) in a community of shared fate (p. 234); and that recasts losses we might mourn as political defeats that might make us rethink our political strategies (pp. 210-218).

This compelling account has a blind spot: The sins of which he accuses other thinkers - abstraction, hypostatization, depoliticization - seem to reappear here not as failings, but as necessary moments in a dialectical approach to responsibility: What are concepts of democracy, socialism, and responsibility if not abstractions from politics - abstractions that are not incidental, but vital to the construction of an account of political responsibility adequate to democratic socialism? The necessity of abstraction becomes clear in a particularly forbidding passage in Vázquez-Arroyo's discussion of mediation in Adorno, which contains this claim: "Whereas the very essence of the concept is to be immediately mediated, the idea of mediation is also mediated by the immediate" (p. 169). I do not take issue with this as an interpretation of Adorno - though I think it calls for more exegesis for readers (including me) who are less familiar with Adorno than he is. I draw attention to it as a particularly stark example of the necessity of abstract conceptual work for even the most political of political thinking.

The same is true of hypostatization. Vázquez-Arroyo notes Adorno's observation that "mediation is mediated" and goes on to say the same for "the two moments that constitute the initial dyad - self-other, subject-object." "[A]s such," he concludes, "mediation cannot be hypostatized" (p. 169). This assertion, which he never really defends, is less persuasive. To see why, recall his criticism of Levinas: While conception of the Other depends upon hypostatization, he recognized that the ethical relationship between self and Other is always mediated (and, for him, defiled) in practice by real politics: by relationships between concrete selves and others. This is why the question of the relationship between ethics and politics is so fraught. In his 1982 interview about the massacres at Sabra and Chatila, Levinas had no illusions about how politics mediated our infinite responsibility to the Other:

The other is the neighbour, who is not necessarily kin, but who can be. And in that sense, if you're for the other, you're for the neighbour. But if your neighbour attacks another neighbour or treats him unjustly, what can you do? Then alterity takes on another character, in alterity we can find an enemy, or at least then we are faced with the problem of knowing who is right and who is wrong, who is just and who is unjust. There are people who are wrong (Levinas, in Hand, 1989, p. 294).

Levinas' hypostatization of the relationship to the Other was thus only a starting point for political reflection. His realist tone here is powerful because it reveals the 
unreality - from a political perspective - of that hypostatized relation. The same seems true of Vázquez-Arroyo's account of mediation. If mediation is mediated, there must be something to mediate. Why is that something not Mediation, understood not as a concrete historical process ("mediation") that takes many forms, but as a philosophical interpretation of the dialectical movement of history just as for Levinas the Other is not a concrete other, but a theological and philosophical interpretation of a primary ethical relation? How can we describe concrete mediations of politics and history without recourse to a concept of Mediation? Like abstraction, then, hypostatization may be a necessary moment in the construction of a political ethic of responsibility, even if it is not the endpoint.

Lastly, there is the charge of depoliticization that drives the entire book. From the perspective of a democratic socialist politics animated by a sense of shared power and a political ethic of responsibility, neoliberalism is indeed depoliticizing in a particular way. From other perspectives - perhaps those that attend more closely the politics of identity than Vázquez-Arroyo does - a democratic socialist vision is also depoliticizing to the extent that it minimizes or marginalizes the politics of race, gender, sexuality, and so on (as, to be sure, does neoliberalism as well). The matter of perspective is thus critical. To "re-cognize" (p. xiii) the political realm demands that we first step back from it, to find a point from which to see. This is not a retreat into neutrality, which is impossible, but a necessary act of perspective-finding that steps away from a particular vision of the political and that is therefore depoliticizing with respect to it. There is, then, no re-cognizing the political without a depoliticizing moment.

This reframing of Vázquez-Arroyo's critique in his own dialectical terms illuminates an unsettling dimension of his argument. Vázquez-Arroyo rightly notes that mediations are also mediated, and so not not immune to political judgment (p. 38). In my judgment, the mediations Vázquez-Arroyo emphasizes threaten to deflect contestation over certain kinds of human suffering. Vázquez-Arroyo describes his own account of political responsibility as one that is "attentive to the forms of power involved in the violent production of superfluous forms of suffering" (p. 23). If some suffering is superfluous, some must be necessary. But how is that necessity determined? Whose suffering is necessary, whose is superfluous, and who decides? These questions reveal a perilous dimension of Vázquez-Arroyo's commitments to democracy, freedom and equality - their realization seems to depend on a prior decision about the value of certain kinds of lives, a decision that has historically devastated marginalized populations people of color, members of LGBTQ etc. communities, the disabled, the stateless, and others as well. It is difficult to argue with the values of freedom, equality, and democracy. But Vázquez-Arroyo leaves at least this reader with the question: Freedom, equality, and democracy for whom, and on whose terms? 


\section{Reference}

Hand, S. (1989). The Levinas Reader. Oxford: Blackwell.

Jade Schiff Oberlin College, Oberlin, OH 44074, USA jade.schiff@oberlin.edu 